\section{Impact of Terms-of-Trade on Slovakia, the Czech Republic, and Croatia in the Short Run ${ }^{1}$}

\author{
Karol Szomolányi \\ Department of Operations Research and Econometrics, University of \\ Economics Bratislava, Slovakia \\ szomolan@euba.sk

\section{Martin Lukáčik} \\ Department of Operations Research and Econometrics, University of \\ Economics Bratislava, Slovakia \\ lukacik@euba.sk

\section{Adriana Lukáčiková} \\ Department of Operations Research and Econometrics, University of \\ Economics Bratislava, Slovakia \\ adriana.lukacikova@euba.sk
}

\begin{abstract}
The terms-of-trade shocks are not main source of business cycles in three postcommunist countries (i.e., Slovakia, the Czech Republic, and Croatia). The zero or negative reactions of the trade balance in terms-of-trade positive shocks in the countries exhibit the Obstfeld-Svensson-Razin effect, according to which the Harberger-Laursen-Metzler positive effect on terms-of-trade indicates that the smaller the trade balance, the more persistent the terms-of-trade shock is The conclusions come from the structural vector autoregressive analysis of the cyclical components of terms-of-trade, trade balance, output, consumption, and investment in three post-communist countries.
\end{abstract}

Key words: innovation, terms-of-trade, business cycle, Slovak economy, Czech economy, Croatian economy, trade balance

\section{Introduction}

This empirical study focuses on the effect of the terms-of-trade shocks in Slovakia, the Czech Republic, and Croatia. We are interested in two effects: the effect of the terms-of-trade shock on the business cycle measured by output, consumption, and investment cyclical components and the effect of the terms-of-trade shock on the trade balance measured by its cyclical component.

Theoretical studies (both traditional and contemporary) have asserted that termsof-trade is a significant source of the business cycle, especially in small open

\footnotetext{
1 This research was supported by the Grant Agency of Slovak Republic - VEGA, grant no. 1/0444/15 "Econometric Analysis of Production Possibilities of the Economy and the Labour Market in Slovakia.”
}

ORIGINAL SCIENTIFIC PAPER

RECEIVED: OCTOBER 2016

REVISED: DECEMBER 2016

ACCEPTED: JANUARY 2017

DOI: 10.1515/ngoe-2017-0001

UDK: $339.5: 330.33 .01$

JEL: C32, E32, F14

Citation: Szomolányi, K., Lukáčik, M., \& Lukáčiková, A. (2017). Impact of

Terms-of-Trade on Slovakia, the Czech Republic, and Croatia in the Short Run. Naše gospodarstvo/Our Economy, 63(1), 3-13. DOI: 10.1515/ngoe-2017-0001

\section{NG OE}

NAŠE GOSPODARSTVO OUR ECONOMY

\section{Vol. 63 No.1 2017}

pp. 3-13 
countries like Slovakia, the Czech Republic, and Croatia. However, empirical studies do not support this theoretical supposition. Aguirre (2011), Broda (2004), and Uribe and Schmitt-Grohé (2016) did not find a statistically significant impact of the terms-of-trade on the output in poor and emerging countries. In this paper, we will confirm the weak effect of the terms-of-trade shock on the business cycles in the three studied countries.

Two theoretical approaches deal with the impact of the terms-of-trade on the trade balance. The first one is the Harberger-Laursen-Metzler effect, which is based on the traditional Keynesian model. Harberger (1950) and Laursen and Metzler (1950) concluded that the effect of the termsof-trade on the trade balance is positive. The second one is the Obstfeld-Svensson-Razin effect, based on dynamic optimizing models. Obstfeld (1982) and Svensson and Razin (1983) stated that the smaller the positive Harberger-Laursen-Metzler effect is, the more persistent the terms-of-trade shock is. Uribe and Schmitt-Grohé (2016) even considered the negative effect of the terms-of-trade on the trade balance under capital adjustment costs. Therefore, we suppose the arbitrary effect of the terms-of-trade shock on the trade balance.

Slovakia, the Czech Republic, and Croatia are small open transition economies. The openness of these economies is relatively high: The international-trade-output ratio is higher than $100 \%$ in Slovakia and the Czech Republic and close to $100 \%$ in Croatia. According to Uribe and Schmitt-Grohé's (2016) definition, these countries are emerging countries. Their average purchasing power parity converted to GDP per capita over the last two decades is within the range of 3,000 to 25,000. The countries are similarly rich as the economies analyzed by Aguirre (2011), Broda (2004), and Uribe and Schmitt-Grohé (2016).

The goal of this paper is to verify the impact of the termsof-trade on the Slovak, Czech, and Croatian business cycles and on the trade balance. A brief economic review is presented in the introduction. We provide an empirical measure based on the structural vector auto-regression (SVAR) econometric specification similar to one presented by Uribe and Schmitt-Grohé (2016). This methodology is described in the following section. We use Slovak and Czech quarterly data from 1997 to 2014 and Croatian quarterly data from 2000 to 2014. Data are gathered from the Eurostat portal. We compute the responses on termsof-trade impulse and variance decompositions of terms-oftrade shocks displayed in the results section. We show that a terms-of-trade shock leads to the immediate decrease in trade balance and has no impact on aggregate output in the analyzed countries. Corresponding interpretations are discussed in the last section.

\section{Theoretical Background}

Uribe and Schmitt-Grohé (2016) described two theoretical effects of the terms-of-trade impact on the trade balance: the Harberger-Laursen-Metzler effect and the ObsfeldSvensson-Razin effect. The Harberger-Laursen-Metzler effect comes from a traditional Keynesian theory. The national accounting identity is in the form:

$y_{t}=c_{t}+g_{t}+i_{t}+x_{t}-m_{t} ; \forall t \in T$

where $y_{t}$ denotes output, $c_{t}$ denotes private consumption, $g_{t}$ denotes public consumption, $i_{t}$ denotes private investment, $x_{t}$ denotes exports, and $m_{t}$ denotes imports in the period $t$ from the given time set $T$. Using a simple Keynesian concept, we assume that private investment and public consumption are both exogenous (autonomous) constants:

$i_{t}=\bar{i} ; \forall t \in T$

and

$g_{t}=\bar{g} ; \forall t \in T$

where $\bar{i}$ and $\bar{g}$ are the parameters. Consumption and imports are increasing functions of output:

$c_{t}=c\left(y_{t}\right)$

and

$m_{t}=m\left(y_{t}\right) ; \forall t \in T$

where marginal propensity to consume and marginal propensity to import are positive and less than 1:

$0<c_{y t}=\frac{\partial c\left(y_{t}\right)}{\partial y_{t}}<1 ; \forall t \in T$

and

$0<m_{y t}=\frac{\partial m\left(y_{t}\right)}{\partial y_{t}}<1 ; \forall t \in T$

The output and all consumption of the aggregate demand $\left(c_{t}+g_{t}+i_{t}\right)$ are expressed in terms of import goods. The quantity of goods exported in period $t$ is denoted by $q_{t}$. Thus, the value of exports in terms of importables, $x_{t}$, is given by: 
$x_{t}=\operatorname{tot}_{t} q_{t} ; \forall t \in T$

where tot $_{t}$ denotes the exogenous terms-of-trade. Quantity of goods exported, $q_{t}$, is assumed to be an autonomous constant given by:

$q_{t}=\bar{q} ; \forall t \in T$

A solution of the model may be expressed by multipliers. The expenditure multiplier is in the well-known Keynesian form:

$\frac{\partial y_{t}}{\partial \bar{i}}=\frac{1}{1+m_{y t}-c_{y t}}>0 ; \forall t \in T$

The Harberger-Laursen-Metzler effect is described by:

$\frac{\partial t b_{t}}{\partial t o t_{t}}=\frac{1-c_{y t}}{1+m_{y t}-c_{y t}} \bar{q}>0 ; \forall t \in T$

where $t b_{t} \equiv x_{t}-m_{t}$ denotes the trade balance.

This effect becomes stronger with a larger volume of exports, $\bar{q}$, a smaller marginal propensity to import, $m_{y y}$, and a smaller marginal propensity to consume $c_{y t}$. Intuitively, a higher value of the marginal propensity to import, $m_{y t}$, weakens the endogenous expansion in aggregate demand to an exogenous increase in exports, as a larger fraction of income is used to buy foreign goods. Similarly, a higher value of the marginal propensity to consume, $c_{y t}$, reduces the Harberger-Laursen-Metzler effect, because it exacerbates the endogenous response of the aggregate demand to a terms-of-trade shock through private consumption.

A disadvantage of the traditional Keynesian model is given by Lucas (1976). The marginal propensity to consume is exogenous. However, according to Friedman's permanent income hypothesis, this propensity depends on endowment shock persistence. In the result, the traditional Keynesian model is independent of whether terms-of-trade shocks are permanent or temporary in nature. However, as the Harberger-Laursen-Metzler effect depends on the marginal propensity to consume, we suppose that the persistence of terms-of-trade shocks is important.

Uribe and Schmitt-Grohé (2016) performed a possible modification of the model. Assume that marginal propensity to consume is an increasing function of the persistence of terms-of-trade shock: $c_{y t}=\alpha(\rho) ; \forall t \in T$

where $\rho$ denotes the (constant) persistence of terms-of-trade shock and

$\frac{\partial \alpha(\rho)}{\partial \rho}>0$

After substituting (12) for the marginal propensity to consume, we can rewrite the Harberger-Laursen-Metzler effect (11) in the form:

$\frac{\partial t b_{t}}{\partial t o t_{t}}=\frac{1-\alpha(\rho)}{1+m_{y t}-\alpha(\rho)} \bar{q}>0 ; \forall t \in T$

The Harberger-Laursen-Metzler effect is smaller the more permanent the terms-of-trade shock is.

The Obsfeld-Razin-Svensson effect is cast within a dynamic optimizing theoretical framework that differs fundamentally from the reduced-form Keynesian model we used to derive the Harberger-Laursen-Metzler effect. Consider the small open economy real business cycle model. The small open endowment economy is inhabited by the infinitely lived representative household, with preferences described by the intertemporal utility function in the form:

$U=E_{0}\left[\sum_{t=0}^{\infty} \beta^{t} u\left(c_{t}\right)\right]$

where $c_{t}$ denotes private consumption and $0<\beta<1$ is a subjective discount factor. The operator $E_{t}$ denotes the expectations operator conditional on information available in the period $t$. The utility, $u$, is a continuously differentiable, strictly increasing, and strictly concave function of consumption; therefore, the marginal utility of consumption is always positive:

$u^{\prime}\left(c_{t}\right)>0 ; \forall t \in\{1,2, \ldots\}$

The marginal utility of consumption is a decreasing function of consumption:

$u^{\prime \prime}\left(c_{t}\right)<0 ; \forall t \in\{1,2, \ldots\}$

We assume that $u\left(c_{t}\right)$ is homogeneous of degree -1 , so that: 
$\frac{u^{\prime}\left(c_{t+1}\right)}{u^{\prime}\left(c_{t}\right)}=\frac{c_{t}}{c_{t+1}} ; \forall t \in\{1,2, \ldots\}$

Assume that the consumption good, $c_{t}$, is imported and the household is endowed with 1 unit of exportable goods in each period. As before, tot denotes the international relative price of exportable goods in terms of importable goods (i.e., terms-of-trade). Then, the household's unit endowment expressed in terms of importable goods is simply tot $t_{t}$. The budget constraint of the representative household in period $t$ is in the form:

$d_{t}=(1+r) d_{t-1}+c_{t}-$ tot $_{t} ; \forall t \in\{1,2, \ldots\}$

where $d_{t}$ denotes the household's debt position in period $t$ expressed in terms of import goods and $r>0$ denotes a constant world interest rate. In terms of import goods in period $t$, the household's endowment, tot ${ }_{t}$, modified by net debt income, $r d_{t}$, is used for the household's consumption, $c_{t}$, and the change of household's debt position. The household and the firm are not allowed to trigger Ponzi games; therefore, a no-Ponzi games constraint must hold in the following form:

$\lim _{j \rightarrow \infty} \frac{1}{(1+r) E_{t}\left(d_{t+j}\right)}=0 ; \forall t \in\{1,2, \ldots\}$

As the economy is small, the evolution of the terms-of-trade, tot $_{t}$, is exogenous, and we suppose that it follows the AR(1) process:

tot $_{t}=\rho$ tot $_{t-1}+\varepsilon_{t}^{t o t} ; \forall t \in\{1,2, \ldots\}$

where $0<\rho<1$ is a serial correlation parameter describing a persistence of the terms-of-trade shocks and $\varepsilon_{t}^{\text {tot }}$ is a normally distributed stochastic term with zero mean and constant variance.

Markets clear when the trade balance of import goods equals endowment (exports) minus consumption (imports):

$t b_{t}=t o t_{t}-c_{t} ; \forall t \in\{1,2, \ldots\}$

The household's debt position equals the net international investment position (i.e., household borrows/lends from/ to abroad). The representative household is in a small open economy; it is such an insignificant agent in the international markets that it takes the world prices $\left\{\text { tot }_{t}, r\right\}_{t=0}^{\infty}$ as given.
Equilibrium is an allocation $\left\{c_{t}\right\}_{t=0}^{\infty}$ so that all markets clear and representative of the household takes the prices $\left\{\text { tot }_{t}, r\right\}_{t=0}^{\infty}$ as given. We can solve the equilibrium as the household problem of choosing the allocation $\left\{c_{t}\right\}_{t=0}^{\infty}$ to maximize utility $U$ subject to the budget constraint (19) in each period $t$ and subject to the no-Ponzi games constraint (20).

The first-order condition of the problem is a Euler equation in the form:

$u^{\prime}\left(c_{t}\right)=\beta(1+r) E_{t} u^{\prime}\left(c_{t+1}\right) ; \forall t \in\{1,2, \ldots\}$

We do not need to form second-order conditions as the utility function is concave in $c_{t}$ and the constraint function is linear in $c_{t}$. We define a deterministic steady-state consumption $c_{t}=E_{t}\left(c_{t+1}\right)$ so that $u_{c t}=E_{t}\left(u_{c t+1}\right)$ in each period $t$, as $u\left(c_{t}\right)$ is homogeneous of degree -1 , therefore $\beta(1+r)=1$.

Considering the no-Ponzi games condition the present value of the real live-time household budget in period $t$ is:

$\sum_{s=t}^{\infty} E_{t}\left[\frac{c_{s}}{(1+r)^{s}}\right]=\sum_{s=t}^{\infty} E_{t}\left[\frac{t_{t o t}}{(1+r)^{s}}\right]-(1+r) d_{t-1} ; \forall t \in\{1,2, \ldots\}$

Let us substitute the steady-state Euler equation and AR(1) into the live-time household budget (24) for consumption and terms-of-trade, respectively, in each period $s$. Then, by solving for consumption, we yield:

$c_{t}=\frac{r}{1+r-\rho}$ tot $_{t}-r d_{t-1} ; \forall t \in\{1,2, \ldots\}$

By substituting (25) into the trade balance (22) for consumption, we yield:

$t b_{t}=\frac{1-\rho}{1+r-\rho}$ tot $_{t}+r d_{t-1} ; \forall t \in\{1,2, \ldots\}$

The Obsfeld-Razin-Svensson effect is:

$\frac{\partial t b_{t}}{\partial t o t_{t}}=\frac{1-\rho}{1+r-\rho} ; \forall t \in\{1,2, \ldots\}$

An increase in the terms-of-trade in period $t$ produces an improvement in the trade balance in period $t$. In response to a mean-reverting increase in export income stemming from an improvement in the terms-of-trade, households consume only part of the additional income and save the rest 
to smooth consumption over time. Consumption increases by less than income, leading to an improvement in the trade balance. The Obsfeld-Razin-Svensson effect states that the effect of terms-of-trade shocks on the trade balance is decreasing in shock persistency $\rho$. Moreover, it is decreasing in interest rate $r$. Households have more incentive to save more in response to temporary shocks than in response to persistent shock. Analogically, the more the households save, the higher the interest rate is.

Intuitively, in countries with high capital costs (i.e., with a high country interest rate spread), the effect of terms-of-trade shocks on the trade balance is very small. This intuition can be theoretically verified using the small open real business cycle model of the production economy. This economy consists of a representative household and a firm. The output is produced by the firm using inputs capital and labor. The output is supposed to be the exports of the economy while the sum of the investment, consumption, and capital costs is supposed to be imports of the economy. An effectiveness of the production is given by the terms-of-trade (instead of the total factor productivity).

Uribe and Schmitt-Grohé (2016) presented the model. Because in the model terms-of-trade shocks are identical to productivity shocks, a persistent increase in the terms of trade induces firms to increase the stock of capital to take advantage of the persistent expected increase of the marginal product of capital in terms of imports. The increase in the desired stock of capital induces a surge in the demand for (imported) investment goods, which tends to deteriorate the trade balance. This negative effect is stronger if imported capital costs are larger. The final effect of terms-of-trade shocks on the trade balance can be negative if both the persistency of the terms of trade shock and the capital costs are sufficiently high.

Using this simple concept with the terms-of-trade instead of the total factor productivity in the production function, the effect of terms-of-trade on the output is clearly positive. This theoretical result is confirmed in the extended small open real business cycle model considering firms producing both importable and exportable goods presented by Uribe and Schmitt-Grohé (2016). The model is more realistic as only a fraction of the GDP is exported. However, as we stated in the introduction, empirical observations do not confirm this theory. Empirically, the effect of the terms-of-trade on the output is negligible.

Uribe and Schmitt-Grohé (2016) extended their model to non-tradable goods, which cannot be exported or imported. Their prices are not equalized across countries because, for various reasons, such as transportation costs and trade barriers, trading them across borders is economically inviable. By calibrating the model, Uribe and Schmitt-Grohé (2016) showed that a model presence of non-tradable goods decreases the theoretical effect of the terms-oftrade on the output. However, this effect is still too high compared to the terms-of-trade effect predicted by the empirical studies.

\section{Methodology}

We used vector autoregressive (VAR) models for our analysis. In VAR models, every endogenous variable is a function of all lagged endogenous variables in the system; see Lütkepohl (2005) for more details about VAR models. The mathematical representation of the unrestricted VAR model of order $p$ is:

$\mathbf{y}_{\mathrm{t}}=\mathbf{A}_{1} \mathbf{y}_{\mathrm{t}-1}+\mathbf{A}_{2} \mathbf{y}_{\mathrm{t}-2}+\ldots+\mathbf{A}_{\mathrm{p}} \mathbf{y}_{\mathrm{t}-\mathrm{p}}+\mathbf{e}_{\mathrm{t}}$

where $\mathbf{y}_{\mathbf{t}}$ is a $k$-dimensional vector of endogenous variables; $\mathbf{A}_{1}, \mathbf{A}_{2}, \ldots, \mathbf{A}_{\mathrm{p}}$ are $k \times k$ matrices of coefficients to be estimated; and $\mathbf{e}_{\mathbf{t}}$ is a $k \times 1$ vector of innovations that may be contemporaneously correlated but are uncorrelated with their own lagged values.

The VAR model (28) can be interpreted as a reduced form model. A structural vector autoregressive (SVAR) model is defined as:

$A \mathbf{y}_{\mathrm{t}}=\mathbf{B}_{1} \mathbf{y}_{\mathrm{t}-1}+\mathbf{B}_{2} \mathbf{y}_{\mathrm{t}-2}+\ldots+\mathbf{B}_{\mathrm{p}} \mathbf{y}_{\mathrm{t}-\mathrm{p}}+\mathbf{B} \mathbf{u}_{\mathrm{t}}$

It is assumed that the structural errors, $\mathbf{u}_{\mathbf{t}}$ are white noise and the coefficient matrices $\mathbf{B}_{1}, \mathbf{B}_{2}, \ldots, \mathbf{B}_{\mathbf{p}}$ are structural coefficients that in general differ from their reduced form counterparts while $\mathbf{B}$ is matrix of restrictions on $\mathbf{u}_{\mathbf{t}}$.

A SVAR model can be used to identify shocks and trace these out by employing impulse response analysis and variance decomposition through an imposition of restrictions on the matrices used. Uribe and Schmitt-Grohé (2016) proposed a specification of the SVAR, through which we can determine responses on terms-of-trade impulse:

$\mathbf{A}\left(\begin{array}{c}t o t_{t} \\ t b_{t} \\ y_{t} \\ c_{t} \\ i_{t}\end{array}\right)=\mathbf{B}_{1}\left(\begin{array}{c}t o t_{t-1} \\ t b_{t-1} \\ y_{t-1} \\ c_{t-1} \\ i_{t-1}\end{array}\right)+\mathbf{B}\left(\begin{array}{l}u_{t}^{t o t} \\ u_{t}^{t b} \\ u_{t}^{y} \\ u_{t}^{c} \\ u_{t}^{i}\end{array}\right)$

where tot is the relative cyclical component of the terms of trade, $t b$ is the relative cyclical component of the trade balance to output ratio, $y$ is the relative cyclical component 
of output, $c$ is the relative cyclical component of consumption, and $i$ is the relative cyclical component of investment. The terms-of-trade is computed as the ratio of export and import deflators. The trade balance is computed as the difference between exports and imports. The output is considered to be GDP, the consumption is considered to be the final consumption of households, and the investment is considered to be the gross capital formation. The last four variables are at constant prices with the reference year 2010. The cyclical components were obtained using the Hodrick-Prescott filter (Hodrick \& Prescott, 1997) with $\lambda=1600$.

The $u_{t}^{\text {tot }}, u_{t}^{t b}, u_{t}^{y}, u_{t}^{c}$, and $u_{t}^{i}$ are structural shocks of the given variables. We estimated the parameters of the SVAR specification (30) using Amisano and Giannini's (1997) approach (AB model, pp. 18-19). The class of commonly used models may be written as:

$$
\mathbf{A e}_{\mathrm{t}}=\mathbf{B} \mathbf{u}_{\mathrm{t}}
$$

The structural innovations $\mathbf{u}_{\mathbf{t}}$ are assumed to be orthonormal-that is, its covariance matrix is an identity matrix $\boldsymbol{\Sigma}_{\mathbf{u}}=\mathbf{I}$. The assumption of orthonormal innovations imposes the following identifying restrictions on $\mathbf{A}$ and $\mathbf{B}$ :

$$
\mathbf{A} \boldsymbol{\Sigma}_{\mathbf{e}} \mathbf{A}^{\mathrm{T}}=\mathbf{B} \mathbf{B}^{\mathrm{T}}
$$

Noting that the expressions on both sides of (32) are symmetric, this imposes $k(k+1) / 2=15$ restrictions on the $2 k^{2}=50$ unknown elements in $\mathbf{A}$ and $\mathbf{B}$. Therefore, in order to identify $\mathbf{A}$ and $\mathbf{B}$, we need to impose $\left(3 k^{2}-k\right) / 2=35$ additional restrictions. The matrix $\mathbf{A}$ of unrestricted specification is a lower triangular matrix with unit diagonal (10 zero and 5 unity restrictions), and matrix $\mathbf{B}$ is a diagonal matrix (20 zero restrictions) in this just-identified specification. Other tested restrictions are imposed on elements of A (matrix of contemporary effects between endogenous variables), which means that our specification becomes over-identified and also testable.

We verified the stability of a VAR model (i.e., whether all roots have a modulus less than one and fall inside the unit circle). We estimated the parameters of restricted and unrestricted specifications. Using the logarithm of the maximum likelihood functions of both specifications, we calculated the likelihood ratio statistics and verified the significance of restrictions. All tests are explained in Greene (2003).

Using the matrix polynomial in lag operator $\mathbf{A}(L)=\mathbf{B}_{\mathbf{1}} L+\mathbf{B}_{\mathbf{2}} L^{2}+\ldots+\mathbf{B}_{\mathbf{p}} L^{p}$ we can rewrite (29) as SMA representation:

$$
\begin{aligned}
\mathbf{y}_{\mathbf{t}}= & {[\mathbf{A}-\mathbf{A}(L)]^{-1} \mathbf{B} \mathbf{u}_{\mathbf{t}}=\mathbf{C}(L) \mathbf{u}_{\mathbf{t}}=\mathbf{C}(0) \mathbf{u}_{\mathbf{t}}+\mathbf{C}(1) \mathbf{u}_{\mathrm{t}-1}+} \\
& +\mathbf{C}(2) \mathbf{u}_{\mathbf{t}-2}+\ldots+\mathbf{C}(h) \mathbf{u}_{\mathbf{t}-\mathbf{h}}+\ldots
\end{aligned}
$$

Hence, $\mathbf{C}(0)$ is the coefficient matrix on impact, $\mathbf{C}(1)$ at a one-period lag, $\mathbf{C}(2)$ at a two-period lag, and so on. Generally, the $\mathbf{C}_{i, j}(h)$ element is the impulse response of variable $i$ to shock $j$ at horizon $h$. The forecast error of $\mathbf{y}$ at horizon $s$ is:

$$
\begin{aligned}
\mathbf{y}_{\mathrm{t}+\mathbf{h}}-\hat{\mathbf{y}}_{\mathbf{t}+\mathbf{h}}= & \mathbf{C}(0) \mathbf{u}_{\mathrm{t}+\mathbf{h}}+\mathbf{C}(1) \mathbf{u}_{\mathrm{t}+\mathrm{h}-\mathbf{1}}+\mathbf{C}(2) \mathbf{u}_{\mathrm{t}+\mathrm{h}-\mathbf{2}}+ \\
& +\ldots+\mathbf{C}(h) \mathbf{u}_{\mathbf{t}}
\end{aligned}
$$

The variance of the forecast error (assuming orthogonality) is expressed as the sum of the individual variances of shocks:

$$
\begin{aligned}
\operatorname{var}\left(\mathbf{y}_{\mathbf{t}+\mathbf{h}}-\hat{\mathbf{y}}_{\mathbf{t}+\mathbf{h}}\right)= & \mathbf{C}(0) \mathbf{I C}(0)^{\mathbf{T}}+\mathbf{C}(1) \mathbf{I C}(1)^{\mathbf{T}}+ \\
& +\mathbf{C}(2) \mathbf{I C}(2)^{\mathbf{T}}+\ldots+\mathbf{C}(h) \mathbf{I C}(h)^{\mathbf{T}}
\end{aligned}
$$

The fraction of the forecast error variance of variable $i$ due to shock $j$ at horizon $h$ is then the $(i, j)$ element of expression (35) divided by the total forecast error variance and is expressed as a percentage. We calculated the impulse response functions (IRF) and realized variance decomposition (VD) to quantify the short-term impact of shocks. Generally, the IRF traces the effect of a one-time shock in one of the innovations on the current and future values of the endogenous variables, and VD is a way to quantify how important each shock is in explaining the variation of each of the variables.

\section{Results}

Slovakia. The responses to the terms-of-trade shock are shown in Figure 1. As the output shock elasticity coefficient was not statistically significant ( 0 is in the two standard deviation interval), the improvement in terms-of-trade had no impact on the aggregate activity, and the one-quarter delayed output expansion was statistically insignificant. Investment displayed a somewhat larger expansion, albeit with a one-quarter delay. Consumption expansion was slightly over the limit of statistical significance. The $10 \%$ increase in the terms-of-trade caused an increase of $1.5 \%$ in consumption. On the other hand, the impact of the termsof-trade shock on trade balance was statistically significant. The $10 \%$ increase in the terms of trade caused a decrease of $7.2 \%$ in trade balance. Furthermore, a larger contraction was delayed by one quarter. The results suggest the confirmation of the Obstfeld-Svensson-Razin effect. 
Figure 1. Impulse response functions to terms-of-trade shock in Slovakia

Response to Structural One S.D. Innovations \pm 2 S.E. Case of Slovakia

Response of TOT to TOT Shock

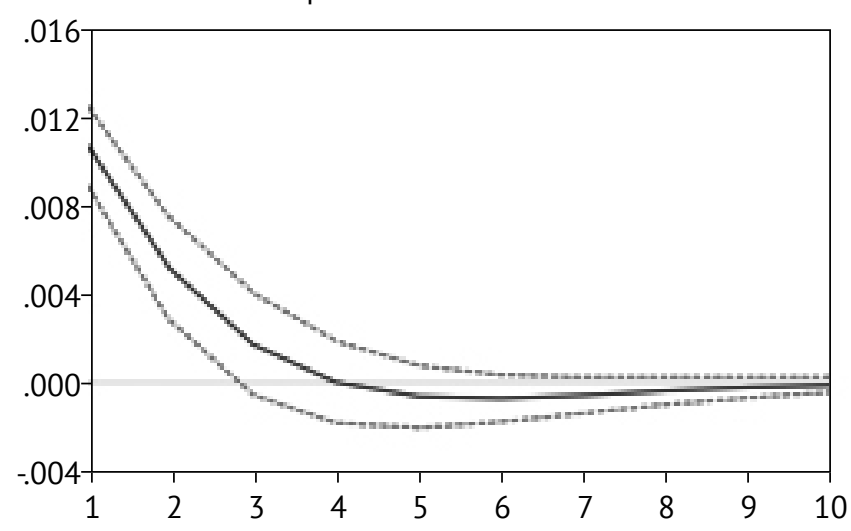

Response of $\mathrm{Y}$ to TOT Shock

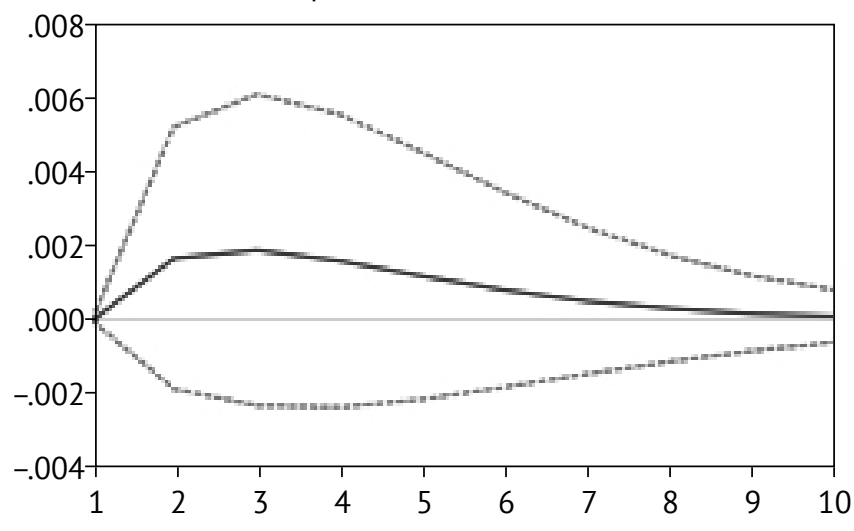

Response of I to TOT Shock

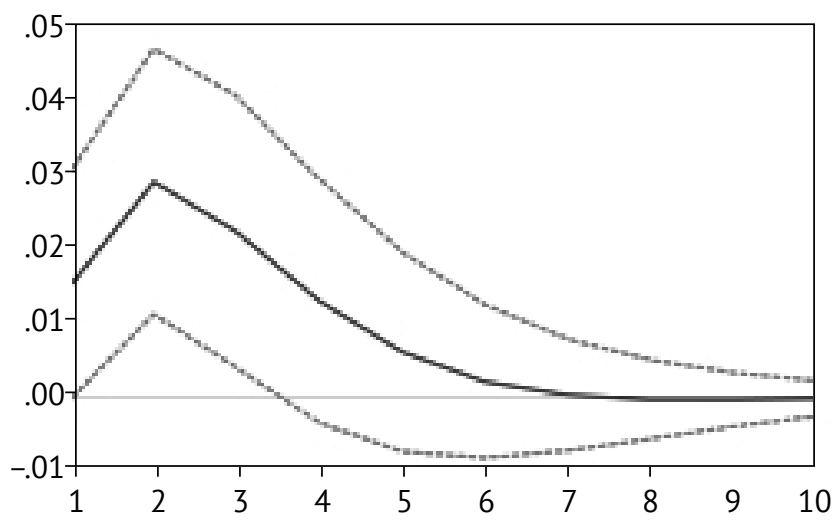

Source: Author's illustration

To gauge the importance of the terms-of-trade shock, we computed the fraction of the variance of all indicators of interest explained by terms-of-trade; in other words, we computed the variance decomposition. The share of variance explained by terms-of-trade shocks in Slovakia was $100 \%$
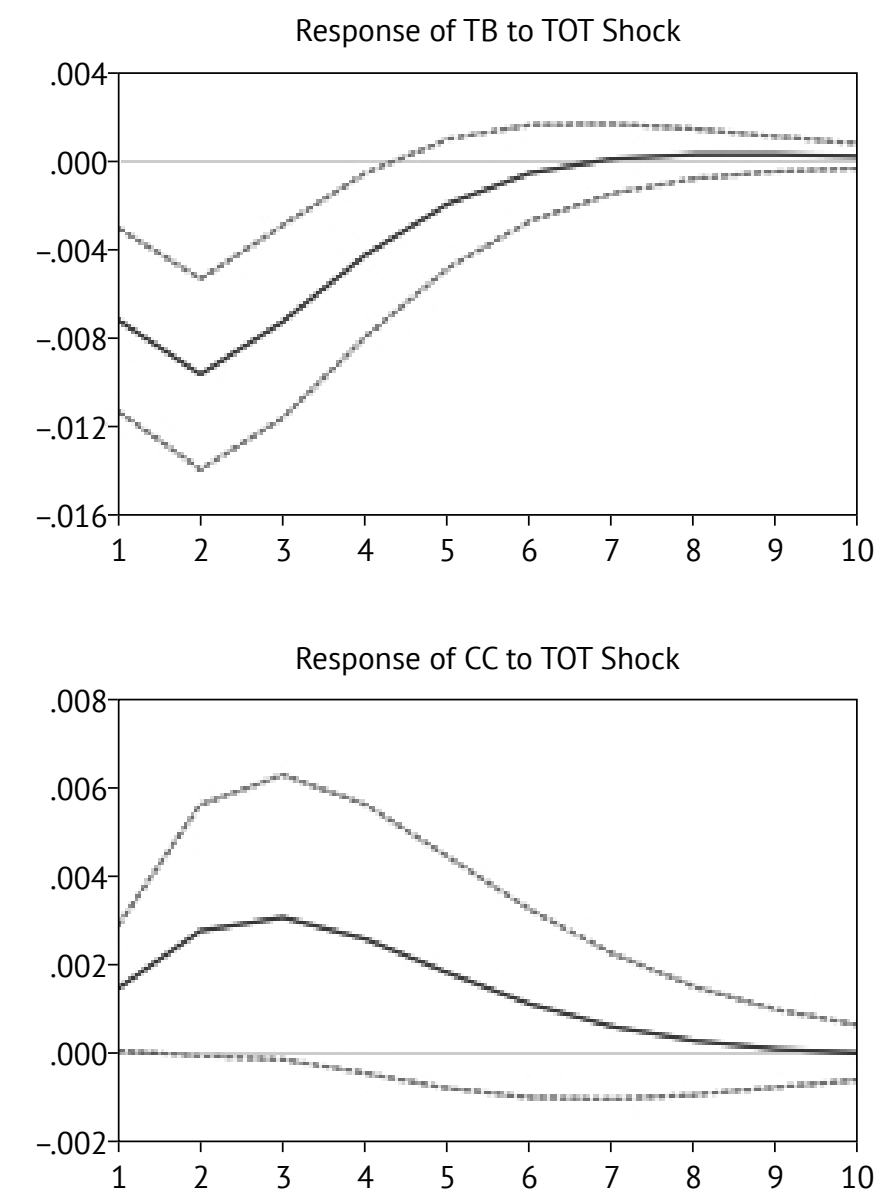
Czech Republic. The responses to the terms-of-trade shock are depicted in Figure 2. As the output shock elasticity coefficient was not statistically significant, the improvement in terms-of-trade had no impact on the aggregate activity, and the one-quarter delayed output expansion was statistically insignificant. Consumption exhibited the same insignificant results as output. Investment expansion was slightly over the limit of statistical significance.
The $10 \%$ increase in the terms-of-trade caused an increase of $6.9 \%$ in investment. The $10 \%$ increase in the terms of trade caused a decrease of $2.1 \%$ in trade balance. As in the case of Slovakia, the results suggest the confirmation of the Obstfeld-Svensson-Razin effect of the terms-of-trade.

The share of variance explained by terms-of-trade shocks in the Czech Republic were $100 \%$ for the variance of

Figure 2. Impulse response functions to terms-of-trade shock in Czech Republic

Response to Structural One S.D. Innovations \pm 2 S.E. Case of Czech Republic
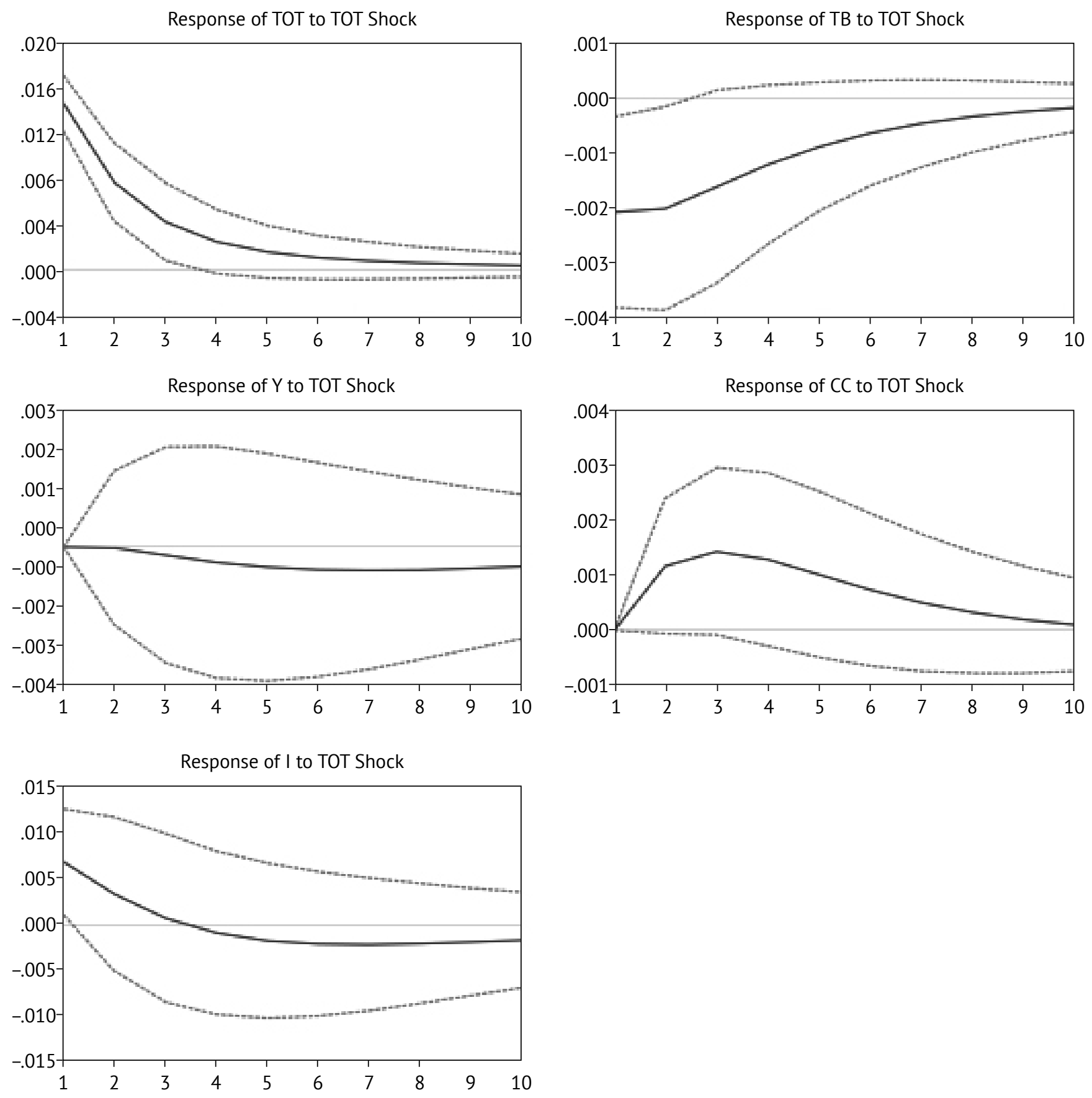

Source: Author’s illustration 
terms-of-trade, $7.7 \%$ for the variance of trade balance, $0 \%$ for the variance of output, $0 \%$ for the variance of consumption, and 3.3\% for the variance of investment.

Croatia. The responses to the terms-of-trade shock are in Figure 3. The improvement in terms-of-trade had no impact on the aggregate activity, consumption, investment, or terms-of-trade. Nevertheless, as in case of Slovakia and the
Czech Republic, the results suggest the confirmation of the Obstfeld-Svensson-Razin effect of the terms-of-trade. The share of variance explained by terms-of-trade shocks in Croatia were $100 \%$ for the variance of terms-of-trade and $0 \%$ for the variances of trade balance, output, consumption, and investment.

Figure 3. Impulse response functions to terms-of-trade shock in Croatia

Response to Structural One S.D. Innovations \pm 2 S.E. Case of Croatia
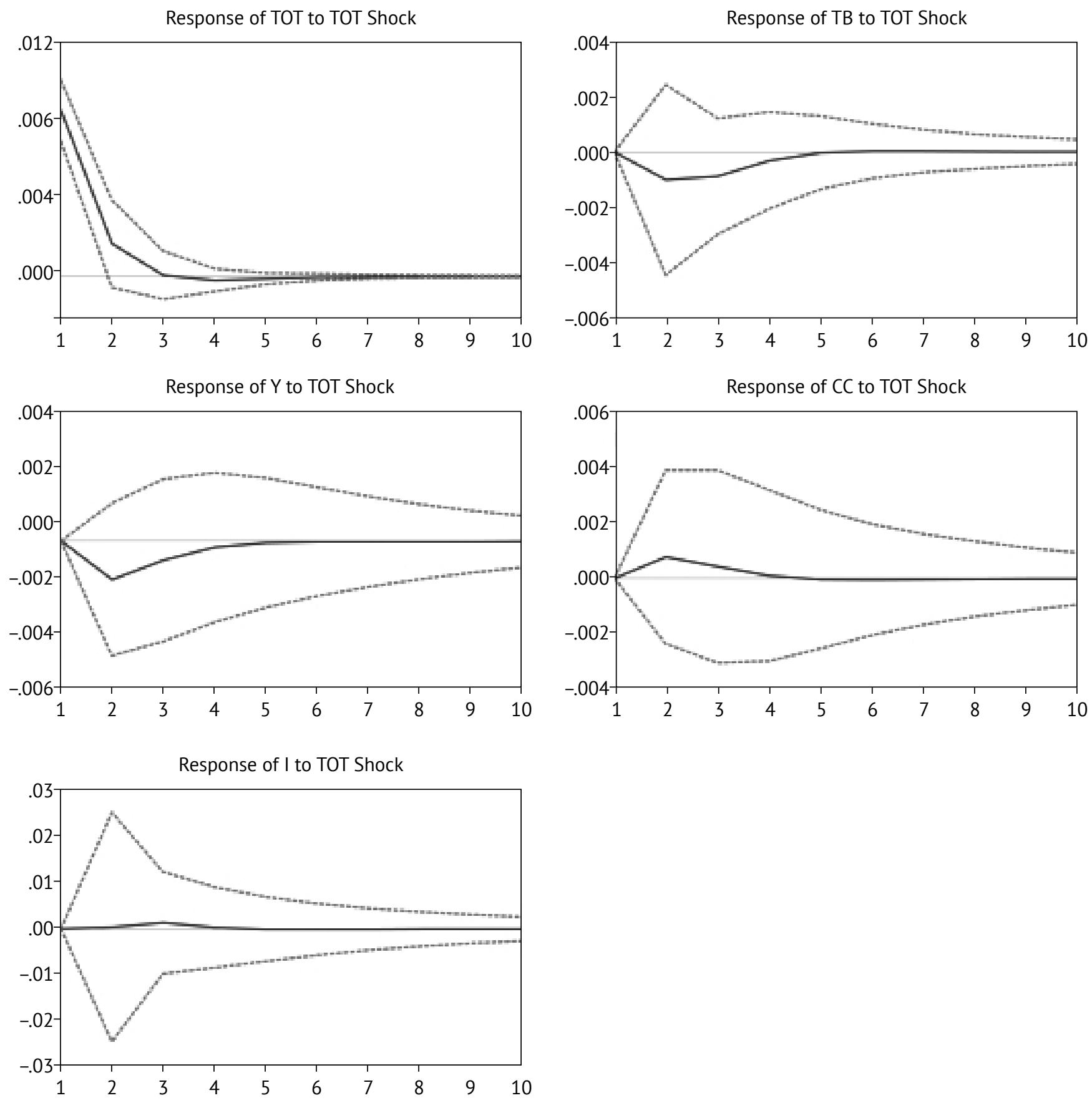

Source: Author's illustration 


\section{Discussion and Conclusion}

The terms-of-trade had a significant impact on the trade balance in Slovakia and the Czech Republic. We could not confirm a statistically significant impact of the terms-oftrade on the trade balance in Croatia. These results support the Obstfeld-Svensson-Razin effect rather than the Harberger-Laursen-Metzler effect. As Uribe and Schmitt-Grohé (2016) showed, this correlation is on average positive in the developing countries around the world. From the theoretical background, it follows that the negative or no effect of the terms-of-trade on the trade balance comes from persistent terms-of-trade shocks or from big capital costs.

However, Szomolányi, Lukáčik, and Lukáčiková (2013) showed that capital costs were not a significant source of the Slovak and Czech business cycles. Using the SVAR analysis of the output, investment, trade balance, world interest rate, and domestic interest rate, they showed that more than $90 \%$ of business cycles were addressed to the output shocks. Therefore, we suggest that terms-of-trade shocks are relatively highly persistent in these two countries. The main imported goods to Slovakia and the Czech Republic have been energy goods such as natural gas and oil. On the other hand, both countries have been exporting mainly cars. In fact, the prices of these goods are changing more consistently than usual.

Our results confirm the empirical evidence of Aguirre (2011), Broda (2004) and Uribe and Schmitt-Grohé (2016) that terms-of-trade shocks explain a very little fraction of the output variance in emerging countries, including Slovakia, the Czech Republic, and Croatia. This evidence can be theoretically explained by the existence of non-tradable goods. A challenge is to form and solve a theoretical model with non-tradable goods explaining the contribution of the trade balance on short-run macroeconomic performance.

The success of the SVAR models in explaining business cycles depends on the correct econometric specification that comes from a proper theoretical model. The specification used in this paper is helpful for understanding that the terms-of-trade shocks do not drive the business cycles in the studied countries. A subject of authors' future research is to form a theoretical model suggesting an appropriate empirical model to identify the main sources of the business cycles in post-communist countries.

\section{References}

Aguirre, E. (2011). Business cycles in emerging markets and implications for the real exchange rate (unpublished Ph.D. dissertation). Columbia University, New York.

Amisano, G., \& Giannini, C. (1997). Topics in structural VAR econometrics (2 ${ }^{\text {nd }}$ ed.). Berlin: Springer-Verlag. https://doi.org/10.1007/978-3642-60623-6

Broda, C. (2004). Terms of trade and exchange rate regimes in developing countries. Journal of International Economics, 63(1), 31-58. https://doi.org/10.1016/S0022-1996(03)00043-6

Greene, W. H. (2003). Econometric analysis (5th ed.). City, NJ: Prentice Hall.

Harberger, A. C. (1950). Currency depreciation, income, and the balance of trade. Journal of Political Economy, 58(1), 47-60. https://doi.org/10.1086/256897

Hodrick, R.J., \& Prescott, E. C. (1997). Postwar U.S. business cycles: An empirical investigation. Journal of Money, Credit and Banking, 29(1), 1-16. https://doi.org/10.2307/2953682

Laursen, S., \& Metzler, L. A. (1950). Flexible exchange rates and the theory of employment. Review of Economics and Statistics, 32(4), 281-299. https://doi.org/10.2307/1925577

Lucas, R. (1976). Econometric policy evaluation: A critique. In K. Brunner \& A. Meltzer (Eds.), The Phillips curve and labor markets (pp. 19-46). New York: American Elsevier. https://doi.org/10.1016/s0167-2231(76)80003-6

Lütkepohl, H. (2005). New introduction to multiple time series analysis. Berlin: Springer. https://doi.org/10.1007/978-3-540-27752-1

Obstfeld, M. (1982). Aggregate spending and the terms of trade: Is there a Laursen-Metzler effect? Quarterly Journal of Economics, 97(2), 251-270. https://doi.org/10.2307/1880757

Svensson, L. E. O., \& Razin, A. (1983). The terms of trade and the current account: The Harberger-Laursen-Metzler effect. Journal of Political Economy, 91(1), 97-125. https://doi.org/10.1086/261130

Szomolányi, K., Lukáčik, M., \& Lukáčiková, A. (2013). Financial world frictions and the Slovak economy. In Kolektiv autorů (Eds.), INPROFORUM 2013 (pp. 295-299). České Budějovice: Jihočeská univerzita v Českých Budějovicích. Retrieved from http://ocs.ef.jcu.cz/index.php/inproforum/INP2013/paper/view/277

Uribe, M., \& Schmitt-Grohé, S. (2016). Open economy macroeconomics. Retrieved from http://www.columbia.edu/ mu2166/book/ 


\section{Authors}

Karol Szomolányi is an associated professor of operations research and econometrics at the University of Economics in Bratislava, Faculty of Economic Informatics, Department of Operations Research and Econometrics. He deals with the macroeconomic analysis and econometrics. His areas of interest are real business cycle models and dynamic stochastic macroeconomic models and their use for developing countries of Eastern Europe. The author can be contacted at karol.szomolanyi@euba.sk.

Martin Lukáčik is an associated professor of operations research and econometrics at the University of Economics in Bratislava, Faculty of Economic Informatics, Department of Operations Research and Econometrics. He is president of the Slovak Society for Operations Research. He deals with the econometric methods in the macroeconomic framework and time series econometrics. His areas of interest are VAR models used in macroeconomics and forecasting methods. The author can be contacted at martin.lukacik@euba.sk.

Adriana Lukáčiková is an assistant professor of operations research and econometrics at the University of Economics in Bratislava, Faculty of Economic Informatics, Department of Operations Research and Econometrics. She deals with computable general equilibrium models and econometrics. Her area of interest is the econometric modelling of national economies. The author can be contacted at adriana.lukacikova@euba.sk.

\section{Kratkoročni vpliv pogojev menjave na Slovaško, Ceško republiko in Hrvaško}

\section{Izvleček}

Šoki zaradi pogojev menjave v treh postkomunističnih državah, tj. v Slovaški, Češki republiki in Hrvaški, niso temeljni vir poslovnih ciklov. Ničelni ali negativni odzivi trgovinske bilance na pozitivne šoke zaradi pogojev menjave v državah kažejo Obstfeld-Svensson-Razinov učinek, za katerega velja, da manjši ko je Harberger-Laursen-Metzlerjev učinek pogojev menjave na trgovinsko bilanco, vztrajnejši je šok zaradi pogojev menjave. Zaključki izhajajo iz strukturne vektorske avtoregresijske analize cikličnih komponent pogojev menjave, trgovinske bilance, izložka, porabe in investicij v treh postkomunističnih državah.

Ključne besede: inovacija, pogoji menjave, poslovni cikel, slovaško gospodarstvo, češko gospodarstvo, hrvaško gospodarstvo, trgovinska bilanca 